\title{
Komunikasi Krisis Pemerintah Daerah Kabupaten Bangka pada Pemberitaan Efek Samping Vaksin COVID-19
}

\author{
Ferdiana $^{1}$, Yuli Hidayati \\ Sekolah Tinggi Ilmu Sosial dan Ilmu Politik Pahlawan 12 \\ Email: ferdianave@gmail.com
}

Diterima : 14 Oktober 2021

Disetujui : 10 Januari 2022

Diterbitkan : 16 Februari 2022

\begin{abstract}
Abstrak
Kasus kematian seorang guru SMP di Pemali Kecamatan Sungailiat Kabupaten Bangka pasca vaksinasi yang terjadi pada awal Mei 2021 masih menimbulkan spekulasi di kalangan masyarakat.Sehingga menimbulkan krisis komunikasi di tengah masyarakat. Penelitian ini bertujuan untuk mengetahui bagaimna komunikasi krisis pada pemberitaan efek samping vaksin covid-19 di Pemerintah Kabupaten Bangka. Penelitian ini menggunakan Teori Komunikasi Krisis Situasional. Jenis penelitian ini dekriptif pendekatan kualitatif. Hasil penelitian pada strategi respons primer antara lain strategi penyangkalan, Pemerintah Kabupaten Bangka berupaya memberikan pengertian kepada masyarakat agar tidak menyimpulkan permasalahan sebelum ada penjelasan lebih lanjut dari ahlinya. Penyelidikan atau investigasi yaitu olehTim Komnas Kejadian Ikutan Pasca Imunisasi (KIPI) dan Komda KIPI Provinsi Kepulauan Bangka Belitung. Strategi pengurangan,memperkuat pandangan bahwa pemerintah Kabupaten Bangka mempunyai tanggung jawab yang tinggi terhadap krisis. Upaya yang dilakukan diantaranya bekerjasama dengan Tim Komnas Kejadian Ikutan Pasca Imunisasi (KIPI) dan Komda KIPI Provinsi Kepulauan Bangka Belitung untuk melakukan investigasi. Strategi pembangunan kembali, Pemerintah Kabupaten Bangka membantu dan mendorong masyarakat untuk melaksanakan vaksin covid-19. Adapun pada strategi respons sekunder yakni strategi penguatan yang dilakukan oleh Pemerintah Daerah Kabupaten Bangka menyampaikan informasi tentang tingkat pelaksanaan vaksin atau keberhasilannya kepada stakeholders, pers BangkaPos, Radio Republik Indonesia Sungailiat dan media massa cetak lain yang ikut merilis.
\end{abstract}

Kata Kunci: Komunikasi, Krisis, Vaksin

\begin{abstract}
The case of the death of a junior high school teacher in Pemali, Sungailiat Sub-district, Bangka Regency after the vaccination that occurred in early May 2021 still raises speculation among the public. This has caused a communication crisis in the community. This study aims to find out how crisis communication is in reporting the side effects of the covid-19 vaccine in Bangka Regency. This research uses Situational Crisis Communication Theory. This type of research is descriptive qualitative approach. The results of the research on the primary response strategy include the denial strategy. The Bangka Regency Government seeks to provide understanding to the community so as not to conclude the problem before there is further explanation from the experts. The investigation or investigation was carried out by the Komnas Team for Post-Immunization Adverse Events (KIPI) and the Komda KIPI for the Province of the Bangka Belitung Islands. The reduction strategy by strengthening the view that the Bangka Regency government has a high responsibility for the crisis. Efforts have been made, including collaborating with the National Committee for Post-Immunization Adverse Events (KIPI) and the KIPI Komda for the Bangka Belitung Islands Province to conduct investigations. For the rebuilding strategy, the Bangka Regency Government helps and encourages the community to implement the COVID-19 vaccine. As for the secondary response strategy, namely the strengthening strategy carried out by the Bangka Regency Government, it conveys information about the level of vaccine implementation or its success to stakeholders, BangkaPos press, Radio Republik Indonesia Sungailiat and other print media also released the release.
\end{abstract}


Keywords: Communication, Crisis, Vaccines

\section{PENDAHULUAN}

Pemerintah Daerah Kabupaten Bangka melalui Dinas Kesehatan yang sudah memulai vaksinasi secara bertahap, namun mengalami kendala akibat krisis komunikasi terkait pemberitaan efek samping vaksin. Salah satunya kasus kematian seorang guru SMP di Pemali pasca vaksinasi yang terjadi pada awal Mei 2021 lalu.Sebelumnya dilaporkan bahwa MG meninggal sepuluh hari setelah menyelesaikan program vaksinasi covid-19. Almarhum suami dari MG yakni Yuli Mulyana, mengakui kebingungannya terhadap penjelasan penyebab meninggalnya istri tercinta. MG mengalami sakit gigi pada saat vaksinasi. Empat hari setelah mendapatkan vaksin Covid-19, ia dirawat di Rumah Sakit Sungailiat Medika dan akhirnya meninggal setelah enam hari perawatan(Tribunews.com,2021).Berikut tangkapan layar terkait postingan pemberitaan tersebut:



Gambar 1. Berita pada laman website Tribunnews tentang guru honorer di Bangka yang meninggal usai sepuluh hari vaksinasi(Tribunnews.com, 2021)

Pemberitaan dengan judul menggunakan "misteri” menggambarkan bahwa penyebab kematian belum diketahui secara pasti, sehingga menimbulkan berbagai spekulasi di kalangan masyarakat. Seiring dengan sedang berjalanan program vaksinasi hingga saat ini di Kabupaten Bangka, maka tidak heran jika ada segelintir masyarakat yang beranggapan bahwa penyebab kematiannya akibat efek vaksin Covid-19. Opini masyarakat tentu saja akan terus berkembang secara liar jika tidak diluruskan. Tersedianya informasi yang memadai merupakan sebuah kewajiban yang harus dilakukan pemerintah sebagai bentuk respons dan pemulihan dari sebuah krisis. (Ayu \& Angendari, 2021). Apalagi penyebaran berita tersebut juga didominasi melalui media yang langsung terhubung dengan internet. Dalam perkembangan teknologi saat ini di Indonesia, internet turut mempengaruhi tingkah laku pengguna informasi yang ada di Indonesia. Salah satu keunggulan internet bagi pengguna adalah kemudahan dan kecepatan dalam mengaksesnya. Ketergantungan terhadap penggunaan internet dalam mencari informasi di masa pendemi covid -19 semakin meningkat tanpa disadari. Berdasarkan laporan modernis.co, pada hasil penelitian oleh ComeScore 
sebesar 8 persen setiap bulan terjadi peningkatan pada pengguna internet media online di masa pendemi, di Indonesia paling tinggi terjadi pada bulan Maret 2020 yakni sebanyak 87 juta orang. (Ilahi \& Syafuddin, 2021). Pengguna internet khususnya media sosial di era pandemi juga memiliki efek luas pada manajemen krisis danmanajemen citra. Media sosial dapat menjadi media yang menimbulkan dampak krisis yang lebih besar dibandingkan media konvensional lainnya.

Pemberitaan melalui media sosial yang sangat beragam terkait efek samping vaksin Covid-19 dapat menjadi peluang sekaligus tantangan bagi pemerintah dalam menghadapi krisis komunikasi di era pandemi ini. Pemerintah dalam menyampaikan informasi terkait penanggulangan covid-19 penuh dengan ketidakjelasan, ambiguitas, dan multitafsir. Hal ini membuat seolah pemerintah menggunakan strategi komunikasi equivocal. Janet Beavin Bavelas mengemukakan komunikasi equivocal adalah narasi-narasi ambiguitas, tidak jelas, dan tidak lugas membuat komunikasi informasi mengenai penanggulangan Covid-19 jadi membingungkan. (Oktariani et al., 2020)

Hal inilah yang menjadi tanggung jawab bersama, agar informasi yang disampaikan khususnya terkait pemberitaan efek samping vaksin tidak menjadi bola panas yang mendestruksi upaya yang telah dibangun. Diungkapkan oleh Laurence Barton bahwa kejadian yang besar dan tidak kita duga serta mempunyai potensi destruktif. Hal ini bisa saja mendestruksi sebuah lembaga atau organisasi, para karyawannya,produk atau jasanya, kestabilan finansialnya bahkan citra organisasi/lembaga tersebut(Putra, 2012). Krisis komunikasi ini dialami oleh pemerintah dalam upaya program vaksinasi Covid-19. Hal ini pada akhirnya menyebabkan masyarakat sebagai target program merasa khawatir akan keamanan vaksin akibat kesimpangsiuran pemberitaan di berbagai media khususnya media online.

Kekhawatiran masyarakat akan dampak vaksinasi covid-19 merupakan gambaran krisis komunikasi di era pandemi saat ini. Pinsdorf mengungkapkan dasar dari komunikasi krisis adalah untuk merespon sesegera mungkin setelah krisis terjadi, melalui transparansi informasi dan kejujuran dengan stakeholders, baik yang terkena efek langsung maupun tidak langsung. Suatu organisasi mempunyai limit waktu minimal yaitu 40 menit sampai paling maksimalnya 12 jam dalam rangka melakukan klarifikasi sebuah krisis versi mereka sendiri. Adapun kepercayaan masyarakat tergantung dari kecepatan dan relevansi dalam penyampaian klarifikasi terhadap krisis yang sedang dihadapi(Indasari \& Anggriani, 2020).Hal ini menjelaskan bahwa respon cepat terhadap sebuah krisis adalah kunci dari keberhasilan sebuah perusahaan untuk mengembalikan kepercayaan terhadap mereka. Begitu pula dengan program pemerintah yang dijalankan oleh pemerintah daerah masing-masing.

Salah satu teori yang digunakan dalam krisis komunikasi adalah Teori Komunikasi Krisis Situasional. Menurut Coombs ada dua strategi dalam merespon krisis dalam Teori Komunikasi Krisis Situasional, yakni strategi respons primer dan strategi respons sekunder. Ada tiga kelompok pembagian dalam strategi respon primer ini, antara lain menyangkal yang merupakan upaya agar krisis yang terjadi tersebut tidak ada kaitannya dengan sebuah organisasi, pengurangan yakni melakukan upaya menurunkan persepsi stakeholders bahwa organisasi mempunyai tanggung jawab yang rendah malah sebaliknya organisasi sangat bertanggung jawab, dan terakhir membangun kembali yaitu upaya dalam menciptakan sebuah citra positif melalui informasi positif tentang organisasi tersebut. Sedangkan strategi respons sekunder adalah penguatan(Amali, 2019).

Pada teori ini, pada dasarnya publik memiliki keputusan tentang krisis dan dapat menjadi penentu pada citra institusi.Hal ini berangkat dari pendangan publik terhad ap sebuah krisis.Apa yang disampaikan pihak manajemen sangat mempengaruhi bagaimana pandangan publik terbentuk terhadap sebuah institusi dan krisis. Dalam teori ini dapat diidentifikasi 
korelasi krisis dengan citra yang bisa dipengaruhi oleh respons dari stakeholders, dan bisa dipahami juga bagaimana publik akan merespons usaha penanggulangan krisis pada masa pascakrisis. (Wuland ari, 2013)

Adapun Pemerintah Daerah Kabupaten Bangka dalam menanggapi krisis komunikasi yang terjadi terkait dengan pemberitaan efek samping vaksin, maka teori komunikasi krisis situasional menjadi teori yang tepat dalam menganalisis hal tersebut. Melalui dua yakni strategi respons primer dan strategi respons sekunder. Pada strategi respons primer Pemerintah Daerah Kabupaten Bangka dapat melakukan penyangkalan terhadap apa yang terjadi pada pemberitaan tersebut, namun tetap terbuka dalam melakukan klarifikasi agar kepercayaan masyarakat segera pulih. Peran Hubungan Masyarakat sangat dibutuhkan untuk mengurangi kekurangan serta ketidakpastian informasi dalam penanganan sebuah krisis (Ulfa, 2019). Selain itu dalam upaya mengurangi dampak dari penyebaran berita Pemerintah Daerah Kabupaten Bangka dapat menggunakan media massa dalam penyebaran informasi khususnya yang terkait klarifikasi maupun informasi positif manfaat vaksin itu sendiri.Kemudian dalam upaya membangun kembali citra terkait program vaksin yang dilakukan maka Pemerintah Kabupaten Bangka dapat bekerjasama dengan berbagai stakeholders agar masyarakat kembali antusias tanpa rasa was-was dalam melaksanakan vaksinasi. Tidak hanya sampai strategi respons primer saja, tetapi pada respons sekunder yakni penguatan, maka Pemerintah Daerah Kabupaten Bangka perlu melakukan upaya memperkuat strategi primer yang dilakukan dan menguatkan kembali kepercayaan masyarakat akan manfaat vaksinasi.

Salah satu penelitian terdahulu yang juga menggunakan teori serupa yakni penelitian Fera Indasari dan Ida Anggraini tahun 2020 dengan judul " Krisis Komunikasi pada masa Pandemi Covid-19 (Studi Kasus Pemberitaan Penyebaran Covid-19 melalui Udara)" dengan hasil penelitian bahwa krisis komunikasi yang terjadi pada WHO (World Health Organization) sebagai sumber informasi kesehatan dunia dapat mengurangi kepercayaan masyarakat dunia, karena kesalahannya dalam menyampaikan informasi terkait penyebaran virus Covid-19 melalui udara. Maka berdasarkan teori krisis, hal yang dilakukan oleh WHO menggunakan metode strategi pembangunan kembali dengan cara membangun kembali kepercayaan tanpa melakukan pengecaman terhadap apa yang dilakukan oleh beberapa peneliti melalui riset mereka bahwa informasi yang disampaikan oleh WHO terkait penyebaran virus melalui udara itu adalah kekeliruan. Lalu WHO sendiri melakukan sebuah pengakuan terhadap kekeliruan yang telah dilakukan kemudian dengan cepat menghapus informasi yang telah diposting melalui laman media khususnya media sosial yang telah tersebar sebelumnya.(Indasari \& Anggriani, 2020). Strategi harus dapat dirancang oleh organisasi pada saat krisis sehingga krisis dapat direspons dengan cepat. Setiap organisasi denagn krisis yang asam akan melakukan respons yang berbeda-beda dalam upaya penanganan sebuah krisis.(Ham et al., 2012). Begitu pula dengan Pemerintah Kabupaten Bangka dalam menghadapi krisis yang dimaksud akan memiliki strategi berbeda juga.

Berdasarkan apa yang telah dipaparkan, maka tujuan dari penelitian ini yakni menganalisis komunikasi krisis pada pemberitaan efek samping vaksin covid-19 di Pemerintah Daerah Kabupaten Bangka. Penelitian ini nantinya diharapkan memberikan implikasi bagi sebuah organisasi dalam upaya menghadapi krisis komunikasi yang terjadi kapan saja. Karena di sisi lain dengannya adanya krisis akan memberikan manfaat bagi sebuah organisasi termasuk institusi Pemerintah Daerah. Hal ini sejalan dengan penjelasan Mejri \& De Wolf kekuatan baru bagi sebuah organisasi dapat terbentuk dari krisis yang terjadi dengan cara menjadikannya pembelajaran (Yulianti \& Boer, 2020). 


\section{METODOLOGI PENELITIAN}

Jenis penelitian ini adalah penelitian deskriptif kualitatif yakni dengan menggambarkan hasil penelitian apa adanya terkait komunikasi krisis Pemerintah Daerah Kabupaten Bangka terkait pemberitaan efek samping vaksin Covid-19. Sedangkan untuk sumber datanya ada dua yakni sumber data primer dan sekunder. Data primer diperoleh peneliti melalui wawancara dengan lima orang stakeholder Pemerintah Kabupaten Bangka yang terkait dalam komunikasi krisis vaksinasi Covid-19. Hal ini sejalan dengan pernyataan bahwa penyelesaian krisis jejaring sosial dari perspektif humas memerlukan analisis dalam penyelesaiannya, yaitu analisis terhadap aktor-aktor yang terkenadampak krisis.Sedangkan sumber data sekunder diperoleh dari studi kepustakaan, dengan mengumpulkan data dan buku di perpustakaan, kemudian jurnal, artikel, internet dan sumber bacaan yang mendukung pada penelitian ini.Selain itu juga melalui dokumentasi yang berasal dari arsiparsip Pemerintah DaerahKabupaten Bangka. Pengumpulan data dilakukan peneliti menggunakan wawancara denganbeberapanarasumber antara lain juru bicara satgas penanganan Covid-19 Pemerintah Daerah Kabupaten Bangka Boy Yandra, SKM, MPH, Kepala Dinas Kesehatan Kabupaten Bangka dr. Then Suyanti, Wartawan Bangka Pos Edwardi, Bapak R seorang Guru SD Sinar Baru, Ibu M (Ibu Rumah Tangga). Kemudian data dikumpulkan melalui dokumentasi terkait penelitian ini, arsip, dokumen, laporan akan dikumpulkan dari masing-masing stakeholder Kabupaten Bangka yang terkait dalam komunikasi krisis tentang berita efek samping vaksinasi Covid-19.

\section{HASIL DAN PEMBAHASAN}

\section{A. Strategi Respons Primer Strategi Penyangkalan}

Pemberitaan mengenai efek samping yang ditimbulkan setelah seseorang divaksin Covid-19 di Kabupaten Bangka akan mempengaruhi masyarakat. Maka dari itu Pemerintah Daerah harus bergerak cepat menangani pemberitaan tersebut. Melalui berbagai strategi diantaranya strategi penyangkalan. Diketahui bahwa Pemerintah Daerah Kabupaten Bangka tidak melakukannya secara terbuka, tetapi lebih pada upaya memberikan pengertian kepada masyarakat agar tidak menyimpulkan permasalahan sebelum ada penjelasan lebih lanjut dari ahlinya. Penyelidikan atau investigasi yaitu olehTim Komnas Kejadian Ikutan Pasca Imunisasi (KIPI) dan Komda KIPI Provinsi Kepulauan Bangka Belitung. Hal ini dijelaskan Juru Bicara Satgas Penanganan covid-19 Kabupaten Bangka Boy Yandra, SKM, MPH sebagai berikut:

"Saat ini masih dalam tahap hasil penyelidikan atau investigasi Tim Komnas Kejadian IkutanPasca Imunisasi (KIPI) dan Komda KIPI Provinsi Kepulauan Bangka Belitung.Jadi kami tekankan pada masyarakat tidak boleh sembarangan membuat kesimpulan karena harus dibuktikan dengan hasil lab dan penyidikan yang dilakukan tim ahlinya. Jadi sebelum hasilnya keluar maka masih ada dugaan bahwa bisa jadi kematian tersebut bukan karena vaksin tetapi akibat komorbid atau penyakit penyerta yang diidap. Tetapi sekali lagi biarkan tim ahli yang akan melakukan tugasnya" (Boy Yandra, 08-07-2021).

Memberikan pengertian kepada masyarakat merupakan bagian dari sebuah komunikasi. Komunikasi ditandai sebagai peringatan, pembicaraan, diskusi, pertukaran pertimbangan atau koneksi. Komunikasi ini juga dapat dipisahkan menjadi beberapa struktur, pembagian komunikasi sejauh penyampaian adalah komunikasi lisan dan tersusun, 
dari beberapa sumber sekarang menambahkan komunikasi elektronik(Kusumawati, 2016). Komunikasi yang dilakukan oleh Pemerintah Daerah Kabupaten Bangka dilakukan dalam bentuk lisan, tertulis hingga elektronik. Komunikasi elektronik sendiri merupakan bagian dari komunikasi massa. Komunikasi massa merupakan proses penyebaran informasi dengan menggunakan media massa.Komunikasi luas dalam lingkup komunikasi massa mencakup surat kabar, majalah, radio, TV atau film. Media massa yang paling umum digunakan di zaman sekarang adalah web(Wilantari, 2018). Hal ini diakui oleh Juru Bicara Satgas Penanganan Covid -19Pemerintah Daerah Kabupaten Bangka dan juga Kepala Dinas Kesehatan Kabupaten Bangka yang menjadi informan dalam penelitian ini. Sebagai salah satu stakeholder Pemerintah Daerah Kabupaten Bangka dalam pelaksanaan vaksinasi, maka Kepala Dinas Kesehatan Kabupaten Bangka Ibu dr. Then Suyanti mengemukakan sebagai berikut:

"Sosialisasi tetap dilaksanakan baik melalui media, secara langsung hingga turun ke desa-desa.Kita tidak bekerja sendiri tetapi seluruh pihak atau kolaborasi semua pihak seperti pihak kepolisian, sekolah-sekolah dan semua pihak"(Then Suyanti, 12 07- 2021)

Diketahui bahwa sosialisasi program vaksinasi telah dilaksanakan melalui kerjasama kolaboratif dengan berbagai pihak melalui berbagai media massa.Salah satu media massa yang cukup populer di Bangka Belintung yang menjadi mitra Pemerintah DaerahKabupaten Bangka adalah Bangka Pos. Sebagai pihak pers, berkewajiban memberikan informasi yang jelas, kredibel serta berkelanjutan, agar perkembangan pemberitaan sampai pada tahap penjelasan oleh orang-orang yang berkompeten. Kewajiban sosial jurnalis yang meliput di suatu media harus independen, objektif dan tepat dalam membuat berita, dan substansi berita yang dibuat harus memiliki komponen pendidikan dan pemahaman sehingga dapat terwakili dengan baik kepada pengguna atau masyarakat umum (Baran, Staley. J., Denis, 2012). Sebagai lembaga pers yang cukup populer di Bangka Belitung, Bangka Pos dalam menyajikan berita yang proporsional. Asumsi dasar tanggung jawab media sosial adalah bahwa media harus bertanggung jawab kepada masyarakat berupa penyediaan berita yang akurat, jujur, objektif dan berimbang(Sapta \& Risdiyanto, 2021).Berikut dijelaskan Edwardi, wartawan Bangka Pos mengenai bagaimana melaksanakan tugas secara proporsional sebagai media informasi masyarakat:

"Tidak ada upaya penyangkalan mengenai efek vaksin karena yang kami buat sebagian besar adalah sosialisasi pelaksanaan sosialisasi vaksinasi covid-19. Bagi masyarakat yang ingin mengetahui tentang vaksin diminta bertanya pada pihak kompeten seperti tim medis ataupun tim satgas penanggulangan covid-19. Begitu pula dengan berita tentang guru SMP yang meninggal pasca 3 hari di imunisasi, peran pers selain memberikan pemberitaan fakta bagi masyarakat tetapi kami tetap melakukan cross check agar berita tersebut dapat diklarifikasi oleh pihak yang mempunyai kompeten dalam hal ini"'(Edwardi, 13-07-2021).

Hal ini juga berlaku pada saat pemberitaan terkait efek samping vaksin covid-19 beredar, sedangkan pemerintah secara nasional termasuk di daerah sedang berusaha untuk melaksanakan program tersebut. Dalam menanggapi pemberitaan vaksin covid-19 agar tidak disebut sebagai krisis yang akhirnya akan mempengaruhi program vaksinasi, maka Pemerintah Daerah Kabupaten Bangka melalui Juru Bicara Satuan Tugas Penanganan Covid-19 Kabupaten Bangka Boy Yandra, SKM, MPH menjelaskan bahwa Tim satgas 
penanggulangan covid-19 tingkat provinsi, kabupaten dan kecamatan bekerjasama selalu menyampaikan kepada masyarakat bahwa efek samping vaksin memang ada tetapi tidak mengkhawatirkan, bahkan ada yang tidak menunjukkan gejala apapun. Bagi masyarakat yang belum vaksin, kemudian mendapatkan informasi simpang siur, maka tim Satgas bersama stakeholders senantiasa melakukan sosialisasi untuk meluruskan informasi.

Firsan Nova mengklarifikasi bahwa keadaan darurat adalah setiap kejadian yang memiliki implikasi mendestruksi reputasi, kemasyhuran, atau stabilitas finansial organisasi. Robert P. Powell juga mengungkapkan bahwa keadaan darurat adalah kejadian yang tidak terduga, memiliki efek emosional, di sana-sini yang luar biasa yang mendorong suatu organisasi menjadi kekacauan. Tanpa aksi yang nyata maka akan menimbulkan desktruksi pada sebuah organisasi. Krisis tidak memiliki batasan sehingga dapat terjadi kapan saja, dimanapun dan bisa terjadi pada setiap organisasi(Arif \& Imran, 2018). Artinya, jika pemberitaan simpang siur terkait efek samping vaksinasi dibiarkan saja, maka akan menimbulkan penurunan kepercayaan masyarakat atas sebuah program yang dilaksanakan Pemerintah termasuk vaksinasi. Dampaknya adalah, kurangnnya antusiasme masyarakat untuk mengikuti vaksin karena ketakutan mereka akan efek yang ditimbulkan nanti.

Diketahui bahwa Pemerintah Kabupaten Bangka cukup serius menghadapi permasalahan dugaan korban meninggal karena vaksin covid-19, yang beritanya cukup ramai diperbincangkan pada saat itu pada 5 Mei 2021 lalu, artikel yang diterbitkan oleh tribunews.com tentang "Guru Honorer di Bangka Meninggal Usai 10 Hari Suntik Vaksin, Penyebab Kematian Masih Misteri” (Tribunnews.com,2021).Pemerintah Daerah Kabupaten Bangka menurunkan tim ahli yang berkompeten dibidangnya, untuk memberikan jawaban yang pasti kepada masyarakat. Hal ini dilakukan sebagai tanda Pemerintah Daerah Kabupaten Bangka berupaya agar permasalahan ini terutama berkembangnya dugaan-dugaan yang salah, akan mengakibatkan masyarakat takut untuk divaksin. Apabila sampai terjadi demikian, maka akan mengurangi kepercayaan masyarakat akan keamanan vaksin yang akan diberikan. Ketidakpercayaan ini pada akhirnya menjadi hambatan dalam optimalisasi pelaksanaan vaksinasi itu sendiri. Kepala Dinas Kesehatan Kabupaten Bangka juga memberikan penjelasan terkait pemberitaan tersebut, pernyataan Kepala Dinas Kesehatan Kabupaten Bangka Ibu dr. Then Suyantibahwa sudah ada klarifikasi tidak ada hubungan dengan vaksin oleh Tim Komnas Kejadian Ikutan Pasca Imunisasi (KIPI) dan Komda KIPI Provinsi Kepulauan Bangka Belitung.Namun, klarifikasi yang dimaksud oleh dr. Then Suyanti tidak melalui media massa, hanya berdasarkan rapat terbatas kalangan tim investigasi saja. Pinsdorf mengungkapkan dasar dari komunikasi krisis adalah untuk merespon sesegera mungkin setelah krisis terjadi, melalui transparansi informasi dan kejujuran dengan para pemangku kepentingan, baik yang terkena dampak langsung maupun tidak langsung. Sebuah perusahaan atau organisasi memiliki batas waktu minimal yakni 40 menit sampai paling maksimalnya 12 jam" dalam rangka melakukan klarifikasi sebuah krisis versi mereka sendiri. Adapun kepercayaan masyarakat tergantung dari kecepatan dan relevansi dalam penyampaian klarifikasi trehadap krisis yang sedang dihadapi(Indasari \& Anggriani, 2020)

Klarifikasi yang dilakukan pihak Pemerintah Daerah Kabupaten Bangka dalam menanggapi kasus dugaan kematian akibat efek samping vaksin dilakukan oleh Kepala Dinas Kesehatan Kabupaten Bangka pada hari yang sama yakni 5 Mei 2021, tetapi informasi hanya sebatas akan menurunkan tim ahli saja belum menjawab pertanyaan masyarakat. Dari segi waktu memang cukup baik karena kecepatan dalam menanggapi. Namun karena informasi tidak disampaikan melalui media massa termasuk media sosial sebagaimana pemberitaan awal tersebar, menunjukkan kurangnya transparansi dari Pemerintah Daerah Kabupaten Bangka untuk memberikan pencerahan terkait klarifikasi kasus dugaan kematian 
akibat efek samping vaksin.Coombs telah menunjukkan bahwa ada tiga prinsip dasar dalam komunikasi krisis, yakni: kecepatan dalam penyampaian pesan, tidak ada penundaan, konsistensi dan transparansi. Kemudian prinsip tranparasi yang mengandung pro dan kontra. Menurut Coombs pro dan kontra hadir karena pemahaman yang tidak sama tentang hal ini. Pemahaman yang pertama tentang transparansi berarti bahwa ada unit ada orang-orang yang secara khusus dalam sebuah organisasi membuat pernyataan dan selalu mempersiapkan diri saat memberikan informasi bagi stakeholders khususnya media. Karena jika terjadi ketidaksediaan untuk berbagi informasi dengan stakeholders tersebut, maka akan ada kesan sebuah organisasi menutupi sesuatu hal.(Prastya, 2011). Apalagi penanganan kasus ini bisa dikatakan waktunya kurang efektif, karena memakan waktu yang cukup lama, hingga klarifikasinya pun tidak disampaikan secara besar-besaran agar kepercayaan masyarakat kembali membaik pada program vaksinasi yang akan dilakukan.

Fearn-Banks menganggap komunikasi krisis sebagai wacana antara asosiasi dan publiknya sebelumnya, selama, dan setelah peristiwa yang merugikan. Prosedur dan strategi wacana yang diperinci dimaksudkan untuk membatasi kerusakan pada gambaran asosiasi. Merencanakan sistem dan strategi pertukaran atau komunikasi untuk membatasi konsekuensi merugikan yang ditimbulkan oleh keadaan darurat pada citra organisasi(Arif \& Imran, 2018). Pada hakikatnya komunikasi krisis mengedepankan komunikasi dua arah antara Pemerintah Daerah Kabupaten Bangka dengan pihak stakeholders yang menjadi sasaran program yakni masyarakat. Maka, dengan tidak terjalinnya komunikasi yang intens dan dua arah tersebut, menimbulkan pertanyaan di benak masyarakat terkait hasil penyelidikan. Apabila komunikator secara leluasa memperoleh umpan balik dari komunikan maka dapat dikatakan komunikasi tersebut berlangsung dua arah. (Ahmad dan Harapan, 2014).

Klarifikasi yang disampaikan Pemerintah Daerah Kabupaten Bangka terkait hasil penyelidikan tidak dilakukan komunikasi dua arah, maka masyarakat sebagai komunikan tidak dapat memperoleh efek dari penyampaian pesan, sekaligus komunikator dalam hal ini pihak Pemerintah Daerah Kabupaten Bangka tidak dapat menerima umpan balik dari masyarakat. Salah satu penyebabnya, karena tidak menggunakan media massa sebagai salah satu taktik dialog untuk meminimalkan dampak krisis tersebut. Salah satu bagian transparansi adalah keterbukaan dan kejujuran yang dapat menjadi kontributor dalam meningkatkan trust masyarakat terhadap organisasi.(Ganjar Runtiko, 2015). Melalui bantuan media massa khususnya media sosial yang umum digunakan, maka secara jelas akan diketahui masyarakat. Umumnya, terutama pada kondisi krisis, semua khalayak organisasi, baik luar maupun dalam, semakin banyak menggunakan internet serta menjadi unit dari respons terhadap krisis melalui pembentukan serta pertukaran pesan (Akhyar \& Pratiwi, 2019). Maka, dengan tidak dimanfaatkannya media massa khususnya media sosial sebagai salah satu media dalam merespons krisis, maka dalam penanganannya, krisis komunikasi terkait pemberitaan efek samping vaksin covid-19 yang terjadi di Pemerintah Daerah Kabupaten Bangka terkesan belum maksimal.

\section{Strategi Pengurangan}

Pemerintah Kabupaten Bangka juga melakukan strategi pengurangan yakni memperkuat pandangan bahwa pemerintah Kabupaten Bangka mempunyai tanggung jawab yang tinggi terhadap krisis. Upaya yang dilakukan diantaranya bekerjasama Tim Komnas Kejadian Ikutan Pasca Imunisasi (KIPI) dan Komda KIPI Provinsi Kepulauan Bangka Belitung untuk melakukan investigasi. Berikut penjelasan Juru Bicara Satgas Penanganan Covid-19 Kabupaten Bangka Boy Yandra, SKM, MPH: 
"Seperti disampaikan sebelumnya, kami sudah bekerjasama Tim Komnas Kejadian Ikutan Pasca Imunisasi (KIPI) dan Komda KIPI Provinsi Kepulauan Bangka Belitung untuk investigasi. Jadi inilah bentuk keseriusan kami dalam menangani hal ini, supaya tidak ada pemberitaan yang simpang siur"(Boy Yandra, 08-07-2021).

Kejadian Ikutan Pasca Imunisasi merujuk pada konteks vaksinasi covid-19 adalah kejadian medik yang diduga memiliki korelasi dengan vaksinasi covid-19 (Peraturan Menteri Kesehatan Nomor 10 Tahun 2021). Pemerintah Kabupaten Bangka memberikan sosialisasi dan informasi secara terus menerus mengenai vaksin covid-19 dan efek sampingnya yang tidak terlalu besar dibandingkan manfaatnya, dengan selalu menyampaikan bahwa peningkatan jumlah kasus positif covid -19 dan jumlah kematiannya. Vaksin menjadi ikhtiar selain menjalankan prokes dengan 3M (menggunakan masker, mencuci tangan dengan sabun dan menjaga jarak).Terkait dengan vaksinasi covid-19, penjelasan tentang kejadian pascavaksinasi sebagai kejadian medis yang diduga terkait dengan vaksinasi. Penggunaan istilah "diduga terkait" menggarisbawahi bahwa KIPI mencakup semua kejadian, baik yang disebabkan oleh vaksin itu sendiri maupun kejadian yang tidak disengaja yang terjadi bersamaan (Peraturan Menteri Kesehatan Nomor 10 Tahun 2021).

Pemantauan dan antisipasi kejadian KIPI di Indonesia, didasarkan pada beberapa aturan, antara lain: Peraturan Menteri Kesehatan Nomor 12 Tahun 2017 tentang Penyelenggaraan Vaksin; Peraturan Menteri Kesehatan Nomor 10 Tahun 2021 tentang Penerapan Vaksin Sebagai Bagian dari Penanganan Pandemi Covid-19, yang telah diubah dengan Peraturan Menteri Kesehatan Nomor 18 Tahun 2021 tentang Perubahan Peraturan Peraturan Menteri Kesehatan Nomor 10 Tahun 2021 tentang Pelaksanaan Vaksinasi Sebagai Bagian dari Upaya Penanggulangan Pandemi Virus Corona 2019 (Covid-19); dan kembali diubah dalam Peraturan Menteri Kesehatan Nomor 19 Tahun 2021 tentang Perubahan atas Peraturan Menteri Kesehatan Nomor 10 Tahun 2021 tentang Penyelenggaraan Vaksin Sebagai Bagian dari Penanggulangan Pandemi Virus Corona 2019 (Covid-19).Sebagai stakeholders dalam pelaksanaan vaksinasi, Dinas Kesehatan Kabupaten Bangka menjelaskan hal serupa bahwa media menjadi kunci penting sebagai salah satu media penyampaiannya. Media memberi peranan penting dalam upaya penyampaian informasi ini. Bagaimana peran pers membantu Pemkab Bangka dalam memberikan sosialisasi mengenai manfaat vaksin covid-19 dan efek sampingnya yang tidak terlalu besar dibandingkan manfaatnya, berikut disampaikan Edwardi, wartawan Bangka Pos:

"Sangat berperan sangat besar, karena beberapa kali dalam kegiatan sosialisasi, ada juga ketua tim satgas yaitu Bupati Bangka menyampaikan sosialisasi pelaksanaan vaksin, beliau membawa bukti selaku pemimpin yang pertama melakukan vaksinasi bersama forkominda jadi total ada 11 orang. Mereka juga membawa sertifikat vaksin dan menjelaskan bahwa efeknya tidak ada yang signifikan. Mereka merasa biasa saja setelah divaksin"(Edwardi, 13-07- 2021).

Pemberitaan yang beragam terkait program vaksinasi ini, baik dalam bentuk sosialisasi hingga pemberitaan efek sampingnya akan diterima oleh masyarakat dengan berbagai persepsi bisa positif atau pun negatif. Senada dengan pendapat Nurudin bahwa informasi dari media massa dapat mempengaruhi orang-orang dalam mengetahui apa yang dianggap baik ataupun tidak baik.(W \& Sudarmanti, 2021).Vaksinasi tentunya tidak dapat diberikan pada semua orang, hal ini karena ada keadaan tertentu yang menyebabkan orang tersebut tidak siap menerima vaksin covid-19. Beberapa kondisi tersebut antara lain: dalam tujuh hari terakhir terinfeksi covid-19 atau ada keluarga yang kontak erat dengan penderita 
covid-19, mempunyai riwayat ISPA seperti batuk, pilek dan sesak napas, ibu hamil dan menyusui, memiliki penyakit bawaan yang berat. (Dukcapil.baritokualakab, 2021).Pada dasarnya sebelum vaksin diberikan pada calon penerima vaksin, maka pihak pelaksana vaksin di Kabupaten Bangka yakni dari Dinas Kesehatan Kabupaten Bangka akan melakukan pemeriksaan terhadap calon penerima vaksin. Mereka akan melakukan cek tekanan darah, hingga menanyakan apakah calon penerima vaksin mengalami gejala mengarah pada covid-19 hingga memiliki penyakit bawaan lain yang sifatnya kronis, sedang hamil/menyusui atau kondisi yang mengarah pada paparan virus covid-19 sehingga beresiko maka vaksinasi akan ditunda atau tidak diutamakan.

Strategi pengurangan yang dilakukan Pemerintah Daerah Kabupaten Bangka dengan mencoba memperkuat pandangan bahwa Pemerintah Daerah Kabupaten Bangka mempunyai tanggung jawab yang tinggi terhadap krisis. Seperti misalnya kerjasama kolaboratif dalam memecahkan misteri kematian guru SMP Pemali yang diduga karena vaksin sebagai pengurangan dari persepsi negatif atas pemberitaan. Selain itu upaya berkelanjutan untuk menjelaskan tingkat capaian pelaksanaan vaksin dan bagaimana orang-orang berpengaruh di Pemerintah Daerah Kabupaten Bangka menjadi role model dalam melaksanakan vaksin. Hal ini bertujuan untuk mempertahankan citranya di kalangan stakeholders termasuk masyarakat terhadap program vaksinasi yang dilakukan. Bagaimana kesigapan Pemerintah Daerah dalam memberikan informasi bagi masyarakat sehingga persepsi masyarakat sepenuhnya positif pada program tersebut. Coombs mengemukakan organisasi yang berada dalam krisis akan berusaha untuk mempertahankan citranya dengan cara melakukan modifikasi tanggung jawab persepsi publik untuk krisis atau untuk mengelola kesan-kesan organisasi itu sendiri (Koswara, 2014).

\section{Strategi Pembangunan kembali}

Strategi pembangunan kembali, Pemerintah Daerah Kabupaten Bangka membantu dan mendorong masyarakat untuk melaksanakan vaksin covid-19 dengan memberikan jadwal pelaksanaan vaksin bertahap untuk usia tua, mudah secara gratis. Selain itu pemberlakukan sistem kupon juga diterapkan untuk mengatasi ketidaktertiban masyarakat karena antuasisme dalam mendapatkan vaksin. Seperti dijelaskan Juru Bicara Satgas Penanganan Covid-19 Kabupaten Bangka Boy Yandra, SKM, MPH:

"Kita buatkan jadwal pelaksanaan vaksin bertahap untuk usia tua, muda secara gratis. Jadi itu upaya kita mendorong masyarakat untuk ikut vaksin"(Boy Yandra, 08-07-2021).

Berdasarkan paparan tersebut, melalui adanya informasi pelaksanaan vaksin dengan "gratis" diharapkan dapat mendorong masyarakat agar melaksanakan vaksin. Dibandingkan dengan studi tahun 2020 oleh Fera Indasari dan Ida Anggraini berjudul "Krisis Komunikasi Selama Pandemi Covid-19 (Studi Kasus Pelaporan Penyebaran Covid-19 Melalui Udara)", hasil studi tersebut mengungkap strategi membangun kembali kepercayaan, tanpa mengkritik tindakan beberapa peneliti yang percaya bahwa WHO melakukan kesalahan dalam mengirimkan informasi ke publik. WHO juga mengaku menyebarkan informasi yang salah ke media dan kemudian menghapus postingan informasi yang berisi perlawanan bahwa virus corona tidak dapat ditularkan melalui udara.Maka hasil penelitian peneliti lebih pada memberikan pelayanan dalam program. Sedangkan penekanan pada konten media sosial yang berisi tentang efek samping vaksin lebih pada penguatan pada informasi besarnya manfaat vaksin dibandingkan dengan efek sampingnya. 
Esensinya strategi pembangunan kembali dalam konteks Komunikasi Krisis Situasional merupakan upaya untuk menciptakan informasi yang positif terkait organisasi. Apa yang dilakukan oleh Pemerintah Daerah Kabupaten Bangka dengan memberikan layanan yang baik bagi masyarakat untuk mendapatkan vaksin, kemudian memberikan informasi manfaat vaksin itu sendiri merupakan upaya untuk membangun kembali kepercayaan publik. Seperti halnya diakui oleh Edwardi, wartawan Bangka Pos mengemukakan peran pers membantu Pemerintah Daerah Kabupaten Bangka mendorong masyarakat untuk melaksanakan vaksin covid-19 sebagai berikut:

"Melalui pemberitaan yang kita buat, dan pernyataan narasumber kita. Hampir setiap hari juru bicara satgas penanggulangan covid-19 Kabupaten Bangka menyampaikan update data perkembangan pasien covid-19 juga selalu melakukan himbauan-himbauan terhadap masyarakat tentang pelaksanaan vaksin di Kabupaten Bangka"'(Edwardi, 13-07-2021).

Pemerintah Daerah Kabupaten Bangka berupaya mengalihkan fokus masyarakat pada pemberitaan efek samping vaksin dengan informasi manfaat vaksin. Informasi lain yang ditambahkan adalah jumlah masyarakat yang telah divaksin secara periode. Kendati Pemerintah Daerah Kabupaten Bangka belum dapat menargetkan ketercapaian vaksinasi karena menunggu distribusi vaksin dari Pemerintah Pusat, namun data yang diperoleh oleh peneliti dari Satgas Penanganan Covid-19 Kabupaten Bangka per 31 Agustus 2021, realisasi vaksin tahap 1 mencapai 67.087 orang $(26,29 \%)$ sedangkan untuk vaksin tahap 2 baru mencapai 41.623 orang $(16,31 \%)$. Jika dibandingkan dengan persentase ketercapaian herd immunity yakni $70 \%$.Salah satu tujuan pelaksanaan vaksinasi covid-19 adalah mencapai kekebalan kelompok di masyarakat (herd immunity) (Peraturan Menteri Kesehatan Nomor 10 Tahun 2021). Melihat dari hasil realisasi pelaksanaan vaksinasi yang telah dilakukan maka tugas Pemerintah Daerah Kabupaten Bangka masih cukup berat untuk mewujudkan hal tersebut. Karena ketercapaian target juga tergantung dari ketersediaan vaksin itu sendiri.

Penyebaran informasi mengenai kebermanfaatkan program vaksinasi covid-19 di Kabupaten Bangka dengan penyampaian jadwal vaksin, pemberian vaksin gratis, hingga terus melakukan up date terkait jumlah korban terpapar Covid-19. Hal ini menjadi upayaupaya Pemerintah Daerah dalam menguatkan kembali posisinya sebagai penyelenggara vaksin dengan tujuan positif yakni meningkatkan herd immunity masyarakat Kabupaten Bangka. Informasi-informasi ini menggambarkan sisi positif Pemerintah Kabupaten Bangka dalam melaksanakan program vaksinasi. Menurut Struges dkk dua fungsi dasar komunikasi selama krisis salah satunya untuk menetralisir intervensi pihak ketiga yang bisa saja memperparah krisis yang sedang dihadapi oleh sebuah organisasi. Pihak ketiga yang melakukan tekanan biasanya adalah pihak media massa, karena fungsi media pada dasarnya memberikan informasi secara riil kepada masyarakat termasuk yang terjadi pada organisasi. Dan tidak jarang pula suasana yang keruh terjadi akibat ulah pemberitaan oleh media massa tersebut, hal ini akan terjadi apabila pihak organisasi tidak terbuka dan enggan memberikan informasi akurat terkait sebuah krisis yang terjadi.Maka dari itu media dapat saja mencari informasi dari pihak lain yang kredibilitasnya belum jelas sehingga menimbulkan suasana semakin panas dan berimbas pada citra dan reputasi organisasi. Maka karena itu Public Relation memiliki keharusan agar dapat cepat dan cekatan untuk meluruskan pemberitaan agar dapat terhindar dari ambiguitas hingga ketidakpastian sebuah informasi. Menyadari akan hal tersebut, maka Pemerintah Daerah Kabupaten Bangka sudah menggandeng mediamedia massa besar yang cukup berpengaruh di Bangka Belitung agar tidak menjadi pihak ketiga yang mengintervensi. Karena pada dasarnya media massa online yang tidak resmi 
maupun oknum-oknum yang kurang mendapat informasi lengkap, sangat berpotensi menjadi pihak yang memperparah keadaan. Dengan sudah menggandeng media massa populer tersebut, maka Pemerintah Kabupaten Bangka mampu membangun kembali citra terhadap program vaksinasi yang telah dilaksanakannya selama ini.

\section{Strategi Respons Sekunder Strategi Penguatan}

Esensi strategi penguatan yakni mengingatkan masyarakat terhadap hal-hal baik yang telah dilakukan sebuah organisasi (Saputra, 2020). Hal ini dapat dilakukan melalui informasi-informasi yang disampaikan melalui media massa. Strategi penguatan yang dilakukan oleh Pemerintah Daerah Kabupaten Bangka menyampaikan informasi tentang tingkat pelaksanaan vaksin atau keberhasilannya kepada stakeholders melalui pers Bangka Pos, Radio Republik Indonesia Sungailiat dan media massa cetak lain yang ikut merilis.

Selain itu, Pemerintah Daerah Kabupaten Bangka memberikan penghargaan bagi stakeholders yang sudah ikut mensukseskan vaksinasi sekaligus menampik isu efek samping vaksinasi, dengan cara melakukan kerjasama berkelanjutan, selalu berkoordinasi karena hingga saat ini vaksinasi masih terus berjalan pelaksanaannya. Selain itu untuk menguatkan bahwa vaksin covid-19 yang diberikan pada masyarakat sudah benar-benar teruji klinis dan halal maka sosialisasi telah dilaksanakan jauh sebelum pelaksanaan vaksinasi dilakukan. Hal ini berkenaan dengan pentingnya menjaga hubungan baik dengan para stakeholder khususnya saat terjadi krisis, sebab analisis stakeholder yang memiliki keterlibatan dalam krisis sangat diperlukan dalam penanganan krisis (Akhyar \& Pratiwi, 2019).

Kunci penting lain untuk mendorong antusiasme masyarakat adalah kebijakan pemerintah pusat yang mewajibkan seseorang menunjukkan kartu atau surat keterangan penerimaan vaks in covid-19 dosis pertama atau dosis penuh seperti penjelasan Kepala Dinas Kesehatan Kabupaten Bangka Ibu dr. Then Suyanti:

"Sekarang yang mendorong harus satu kesatuan pemerintah. Sekarang sudah bagus karena kebijakan Pemerintah sudah mendorong seperti harus adanya sertifikat vaksin bagi yang mau bepergian ke luar kota. Jadi kebijakan sudah mendukung maka kami hanya pelaksana"'(Then Suyanti, 12 -07-2021).

Adapun beberapa kebijakan yang dimaksud seperti Surat Edaran Nomor 16 Tahun 2021 Peraturan Daerah untuk dalam negeri. pemudik di era pandemi Corona virus disease 2019 (covid-19) (khusus pemudik jarak jauh yang menggunakan perjalanan udara dari dan ke pulau Jawa dan pulau Bali, serta wilayah yang tergolong wilayah dengan kategori aktivitas masyarakat level 4 dan level 3. Penerapan Pembatasan (PPKM) dan PPKM Tingkat 3). Lampiran Surat Edaran (SE) Pokja Manajemen Nomor 8 Covid-19 Tahun 2021 tentang protokol kesehatan dalam perjalanan internasional selama masa pandemi Corona Virus Disease 2019 (Covid-19). Sementara itu, Bangka Belitung dikenal sebagai Kategori Penegakan Pembatasan Kegiatan Masyarakat (PPKM) Level 4 dan Level 3.

Penguatan yang dilakukan oleh Pemerintah Daerah Kabupaten Bangka terkait program vaksinasi bertujuan untuk kembali meraih kepercayaan masyarakat secara penuh. Tetapi penggunaan kebijakan Pemerintah Pusat bahwa sertifikat vaksin sebagai syarat perjalanan, malah mendapat tanggapan beragam. Tidak sedikit masyarakat yang mengeluh dan tujuannya ikut vaksin karena khawatir tidak dapat keluar daerah. Padahal kesukarelaan untuk divaksinasi setiap lapisan masyarakat sebagai bentuk kesadaran baghwa vaksinasi adalah demi kebaikan seluruh masyarakat Indonesia. Maka dari itu, penguatan yang harus 
dilakukan adalah mengupayakan masyarakat secara sadar dan sukarela dalam mendapatkan haknya untuk sehat melalui vaksinasi dengan memberikan kesempatan pada pemerintah melakukan kewajibannya untuk menyehatkan masyarakat.

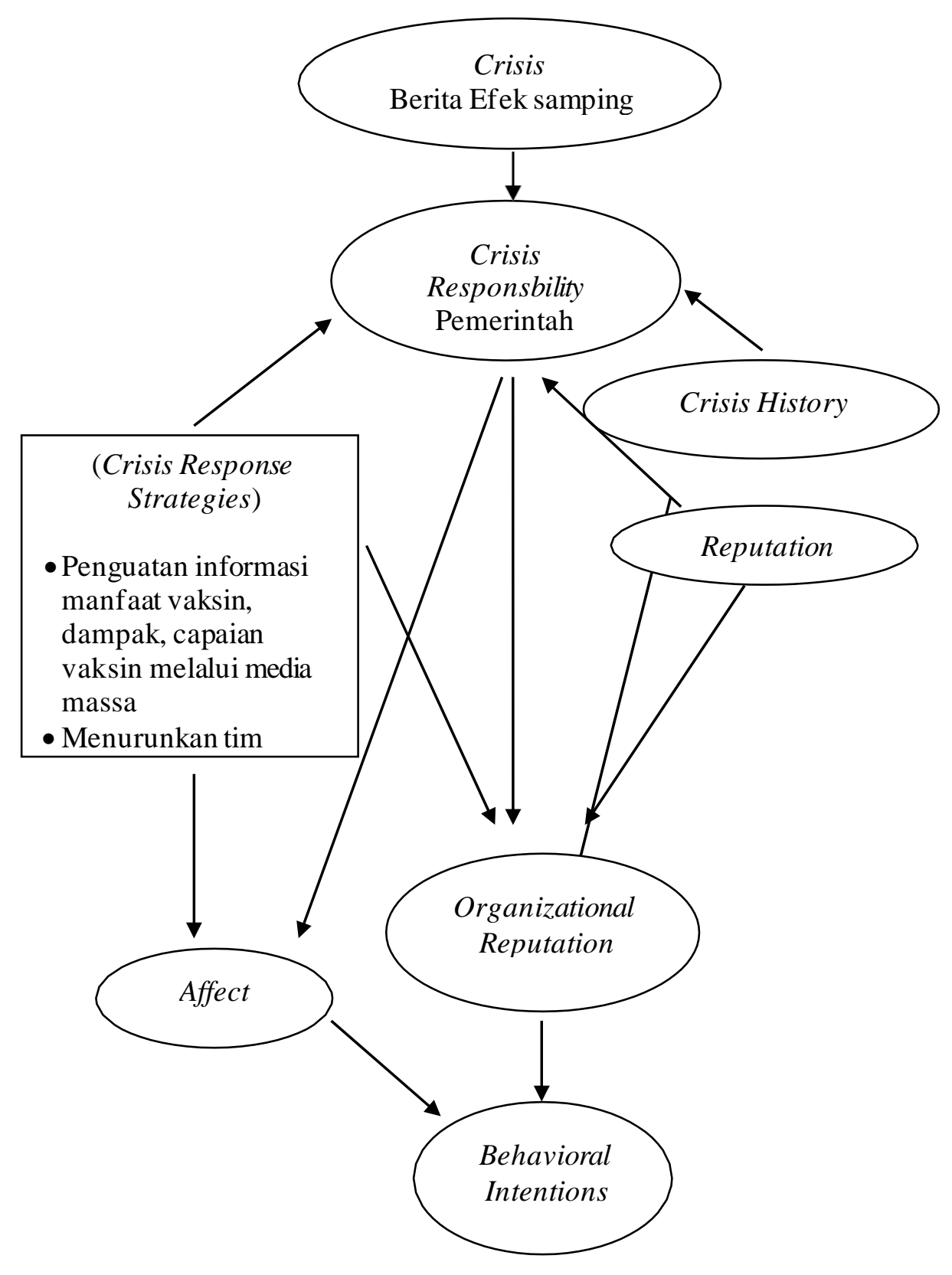

Gambar 2. Komunikasi krisis Pemerintah Kabupaten Bangka terkait berita efek samping vaksin menggunakan model Komunikasi Krisis Situasional

Model diatas menggambarkan bagaimana Pemerintah DaerahKabupaten Bangka sebagai penanggung jawab krisis berita efek samping vaksin covid-19 dengan menerapkan beberapa strategi seperti penguatan informasi manfaat vaksin, dampak, capaian vaksin melalui media massa, menurunkan tim investigasi KIPI Kabupaten Bangka dan Komda KIPI Provinsi Bangka Belitung, serta bekerjasama dengan stakeholder yang merupakan bentuk strategi respons primer maupun respons sekunder. 


\section{PENUTUP}

Komunikasi krisis pada pemberitaan efek samping vaksin covid-19 di Pemerintah Daerah Kabupaten Bangka pada strategi respons primer antara lain strategi penyangkalan Pemerintah Kabupaten Bangka berupaya memberikan pengertian kepada masyarakat agar tidak menyimpulkan permasalahan sebelum ada penjelasan lebih lanjut dari ahlinya. Penyelidikan atau investigasi yaitu olehTim Komnas Kejadian Ikutan Pasca Imunisasi (KIPI) dan Komda KIPI Provinsi Kepulauan Bangka Belitung. Kemudian strategi pengurangan dengan memperkuat pandangan bahwa pemerintah Kabupaten Bangka mempunyai tanggung jawab yang tinggi terhadap krisis. Upaya yang dilakukan diantaranya bekerjasama Tim Komnas Kejadian Ikutan Pasca Imunisasi (KIPI) dan Komda KIPI Provinsi Kepulauan Bangka Belitung untuk melakukan investigasi, menjelaskan tingkat capaian pelaksanaan vaksin dan bagaimana orang-orang berpengaruh di Kabupaten Bangka menjadi role model dalam melaksanakan vaksin. Untuk strategi pembangunan kembali Pemerintah Daerah Kabupaten Bangka membantu dan mendorong masyarakat untuk melaksanakan vaksin covid-19.Penyebaran informasi mengenai kebermanfaatkan program vaksinasi covid-19 di Pemerintah Daerah Kabupaten Bangka dengan penyampaian jadwal vaksin, pemberitaan vaksin gratis, hingga terus melakukan up date terkait jumlah korban terpapar Covid-19. Adapun pada strategi respons sekunder yakni strategi penguatan yang dilakukan oleh Pemerintah Daerah Kabupaten Bangka menyampaikan informasi tentang tingkat pelaksanaan vaksin atau keberhasilannya kepada stakeholders melalui pers Bangka Pos, Radio Republik Indonesia Sungailiat dan media massa cetak lain yang ikut merilis.

Maka beberapa hal yang direkomendasikan oleh peneliti jika dikaitkan dengan teori Komunikasi Krisis Situasional maka pada strategi respon primer yakni penyangkalan harusnya Pemerintah Daerah Kabupaten Bangka menolak tegas pemberitaan tersebut disebut sebagai krisis.Lalu pada strategi pengurangan Pemerintah Daerah Kabupaten Bangka meminimalisir tanggung jawabnya dengan menyangkal bahwa Pemerintah Kabupaten Bangka tidak mungkin dengan sengaja menyebabkan krisis atau krisis terjadi di luar kendali institusi.Pada strategi pembangunan kembali Pemerintah Daerah Kabupaten Bangka harusnya memberikan bantuan bagi keluarga korban yang diberitakan serta meminta maaf pada publik atas apa yang disangkakan dan akan sesegera mungkin melakukan klarifikasi. Sedangkan pada strategi respon sekunder yakni penguatan harusnya Pemerintah Daerah Kabupaten Bangka dapat memberitahukan juga pada stakeholders bahwa institusi juga termasuk korban dari krisis yang ada.

\section{REFERENSI}

Ahmad dan Harapan. (2014). Komunikasi Antarpribadi. Raja Grafindo Persada.

Akhyar, D. M., \& Pratiwi, A. S. (2019). Media Sosial dan Komunikasi Krisis : Pelajaran dari Industri Telekomunikasi di Indonesia. Jurnal Ilmu Komunikasi ULTIMACOMM, 11(1), 35-52.

Amali, M. T. (2019). Strategi Komunikasi Krisis Public Relations Pt. Lion Mentari Airlines Dalam Merespon Kasus Kecelakaan Pesawat Lion Air Jt610. Jurnal Audience, 2(2), 116-134. https://doi.org/10.33633/ja.v2i2.2709

Arif, A., \& Imran, A. I. (2018). Analisis Strategi Komunikasi Krisis Humasda PT. Kereta Api Indonesia (Persero) Daerah Operasional 2 Bandung. Jurnal Sosial Keagamaan, 2(1), 1-10.

Ayu, D., \& Angendari, D. (2021). Menelaah Pesan Pemerintah terkait Krisis Covid-19 di Media Sosial. 4, 247-260.

Baran, Staley. J., Denis, K. (2012). Mass Communication Theory: Foundation, Ferment,and 
Future, (Sixth Edit).

Dukcapil.baritokualakab. (Maret, 2021). syarat-syarat orang yang boleh divaksin corona. https://dukcapil.baritokualakab.go.id/baca-berita-210-syaratsyarat-orang-yang-bolehdivaksin-corona.html

Ganjar Runtiko, A. (2015). Krisis dan komunikasi pada masyarakat miskin perdesaan. 3(1), $1-14$.

Ham, C. D., Hall, G., Urbana, S. W. S., Korea, S., \& Cameron, G. T. (2012). Same Crisis , Different Responses: Case Studies of How Multiple Competing Corporations Responded to the Same Explosion-Related Crises Department of Advertising Department of Advertising \& Public Relations. 3(20), 19-31.

Ilahi, F. K., \& Syafuddin, K. (2021). Konsumsi Pemberitaan Media Online di Masa Pandemi oleh Ikatan Pelajar Riau Yogyakarta ( IPRY-KB) Komisariat Bengkalis Selama. 4, 275-292.

Ind asari, F., \& Anggriani, I. (2020). Krisis Komunikasi Pada Masa Pandemi Covid-19 (Studi Kasus Pemberitaan Penyebaran Covid-19 melalui Udara). Profesional: Jurnal Komunikasi Dan Administrasi Publik, 7(1), 1 11. https://doi.org/10.37676/professional.v7i1.1086

Koswara, A. (2014). Komunikasi Krisis : Analisis Upaya Respon Krisis Teluk Meksiko Dari Perspektif Public Relations "A reputation once broken may possibly be repaired, but the world will always keep their eyes on the spot where was the crack " (Joseph Hall) (1), 107-131.

Kusumawati, T. I. (2016). Komunikasi Verbal Dan Nonverbal. Jurnal Pendidikan Dan Konseling, 6(2).

Oktariani, R., Eka, A. G., \& Wuryanta, W. (2020). Komunikasi Pemerintah Melalui Media Center Gugus Tugas Percepatan Penanganan Covid-19 Kepada Publik. 03(02), 113123. https://doi.org/10.33021/exp.v3i2.1196

Peraturan Menteri Kesehatan Nomor 10 tahun 2021, Pub. L. No. 10 (2021).

Prastya, N. M. (2011). Komunikasi Krisis di Era New Media dan Social Media Narayana Mahendra Prastya Mahasiswa Pascasarjana Komunikasi Universitas Gadjah Mada (UGM), Yogyakarta. Jurnal Komunikasi, 6, 1-20.

Putra, O. W. M. (2012). Manajemen Krisis Pt. Lion Mentari Airlines Dalam Menangani Berita-Berita Negatif Di Media Massa. Skripsi Ilmu Komunikasi.

Putri, L. D. (2014). Krisis , Ancaman atau Peluang ?! Oleh Fakultas Ilmu Sosial dan Ilmu Politik Universitas Serang Raya Abstrak perusahaan tumbuh dan berkembang di dalam masyarakat yang memiliki segala macam aturan . Dari kewajaran diatas, maka amatlah perlu seorang pemimpi.

Sapta, \& Risdiyanto, B. (2021). Peran Jurnalis Selama Pandemi Covid-19 Melalui Pemberitaan.8(1).

Saputra, R. (2020). Penerapan Situational Communication Crisis Theory bagi Organisasi Dakwah dalam Menghadapi Situasi Krisis. 6(2), 190-201.

Tribunews.com. (Mei, 2021). Guru Honorer di Bangka Meninggal Usai 10 Hari Suntik Vaksin, Penyebab Kematian Masih Misteri. https://doi.org/https://www.tribunnews.com/regional/2021/05/05/guru-honorer-dibangka-meninggal-usai-10-hari-suntik-vaksin-penyebab-kematian-masih-misteri

Ulfa, N. (2019). Manajemen Krisis Humas Pemerintah Daerah Kabupaten Lombok Utara Pada Saat Gempa Bumi Lombok 2018 Crisis Management of North Lombok District Government Public Relations During The Lombok Earthquake In 2018. 2(2), 5-8.

W, I. C., \& Sudarmanti, R. (2021). Pengaruh Pemberitaan Media Massa terhadap Persepsi Masyarakat tentang Susu Kental Manis. Ekspresi Dan Persepsi : Jurnal Ilmu 
Komunikasi, 4(1), 80. https://doi.org/10.33822/jep.v4i1.2211

Wilantari, N. N. A. (2018). Komunikasi Massa Dalam Pariwisata Religi Hindu. Satya

Widya: Jurnal Studi Agama, 1(2), 139-152. https://doi.org/10.33363/swjsa.v1i2.42

Wulandari, T. D. (2013). Pengaruh Tanggung Jawab Perusahaan dalam Menanggulangi Krisis terhadap Reputasi Perusahaan. Jurnal Ilmu Komunikasi, 8(2), 1-13. https://doi.org/10.24002/jik.v8i2.175

Yulianti, W., \& Boer, R. F. (2020). Manajemen krisis public relations dalam menangani penolakan imunisasi measles rubella. 4(2), 290-311. 